\title{
Immovable Object: North Korea's 70 Years at War with American Power. By Abrams, A. B. Atlanta: Clarity Press, 2020. 676 p [ISBN: 9781949762300]
}

John Cussen*

\section{Impossible or Immovable?}

By its heft and by its title, A.B. Abrams's 676-page Immovable Object: North Korea's 70 Years at War with American Power signals its wish to displace on our DPRK bookshelves Victor Cha's The Impossible State: North Korea, Past and Future. Yes, no less a book than Cha's- the "excellent, comprehensive,"1 "intelligent,"2 and "informative,"3 albeit selfvindicating, ${ }^{4}$ volume put out some nine years ago by the not-long-before,

* Edinboro University, jcussen@edinboro.edu

1 Jonathan Fenby. "Kim's Nuclear-Powered High-Wire Act." Times, The (United Kingdom), August 13, 2012, 28. https://search.ebscohost.com/login.aspx?direct= true $\& \mathrm{db}=\mathrm{nfh} \& \mathrm{AN}=7 \mathrm{EH} 62908572 \&$ site=ehost-live.

2 Thomas Wilkins. "Book Review - The Impossible State: North Korea Past and Future." The Diplomat, Sept. 3, 2012, https://thediplomat.com/2012/09/bookreview-the-impossible-state-north-korea-past-and-future/. Accessed Nov. 21, 2021.

3 Hwang, Philip. "The Impossible State: North Korea Past and Future by Victor Cha." American Foreign Policy Interests 36, no. 3 (May 2014): 212-14. doi:10.1080/10803920.2014.925343.

4 Hazel Smith. "Book Review: The Impossible Stare: North Korea Past and Future." LSE Review of Books, July 24, 2012. https://blogs.lse.ac.uk/lsereviewofbook s/2012/07/24/book-review-the-impossible-state-north-korea-past-and-future/. Accessed Nov. 22, 2021. 
George W. Bush era, Asian Affairs Director of the National Security Council. And what's wrong with that? Cha's book's getting pushed aside by Abrams's, that is? Nine years is not an insignificant amount of time in matters realpolitik; and, further, when one starts thinking about it, a good deal has happened in the North Korean orbit since 2012 and the arrival of the resonantly titled The Impossible State. The three landmark Summits of 2018 and 2019 first come to mind. But also, too, several lesser events on the North Korean happenings list, such as, for example, the Sony Pictures cyber-attacks of late 2014-wherein, if nothing else, the coming-of-age Kim Jong Un demonstrated his and his regime's acute sensitivity to questions of Information and Public Opinion Warfare ${ }^{5}$ - and, such as too, of yet more recent date, the North's testing of a submarine-launched ballistic missile in October of last year-wherein, it's thought, Kim and his generals were signaling to Biden their never-much-abated commitment to door-die, stand-and-resist military postures. ${ }^{6}$ Again, as per Cha's book's continued serviceability, one wonders if the terms of his analysis are any longer relevant. When he defines the DPRK, for example, as "a Cold War anachronism" (7), he is, it would seem to most of us, either giving too much credit to an evolved, geopolitical world order or too little. Yet more problematic is that chapter in his book which is titled "Complete, Verifiable, and Irreversible Dismantlement (CVID)." I say this because what the chapter does primarily is remind us that there once were ambassadorial types like Cha himself blowing smoke of that steroidal ilk at high-level negotiating tables while folk on the table's North Korean side mostly

5 SMITH, PATRICIA, Nicole Perlroth, and David E. Sanger. "CYBERWAR: THE U.S. vs. NORTH KOREA.” New York Times Upfront 147, no. 8 (February 2, 2015): 14-15. https://search.ebscohost.com/login.aspx?direct=true\&db=ulh\&AN= $100973379 \&$ site $=$ ehost-live.

6 Ray, Siladitya. "North Korea Confirms Submarine-Launched Missile Test as White House Warns against Further 'Provocations,"” Forbes, Oct. 20, 2021, https://www.forbes.com/sites/siladityaray/2021/10/20/north-korea-confirms-subma rine-launched-missile-test-as-white-house-warns-against-further-provocations/?sh= 4387062c78bc. Accessed Nov. 23, 2021. 
laughed. Next, the good deal more that we know now about Kim Jong Un's leadership style and capacities than we did in the first weeks of his ascendency — which was when Cha finished up his text — this too weighs against his book's continued usefulness. And, lastly, Cha's The Impossible State has this other deadweight hanging from its neck-its prediction that the DPRK had at best some eight more years of life left in its faltering engine. No, despite the contradictory imperatives that would seem to be its hard-luck, real-world situation, namely, the need to open up its markets and the need to shut down oppositional thoughts whenever and wherever they should surface, that prediction has clearly not panned out.

So, given Cha's text's weaknesses, what's the harm in replacing it with another? It's this: the strong likelihood that its replacement might come from so far to the opposite side of the ideological table that it would require us to buy into some very questionable propositions. And that, unfortunately, is what I largely find happening in Immoveable Object. Questionable at the very least, for example, is the judgment that, in 1945, the fledgling People's Republic of Korea was on an entirely benign, stable course when in the fall of that year the US forces then arriving in country ruled against its continuance. No, in actual fact, several were the claimants to the suddenly nascent Korean state's executive office in the year of the Americans' arrival, and, though, yes, the KPR's Yeo Un-hyeong was the claimant most in the forefront, it's also true that he and his party did indeed lean far more to the left than to the right in the year of the Americans' arrival and, for a short time thereafter anyway, continued to do so. ${ }^{7}$ Also, as the Americans saw things in that first Cold War year, the Soviets were very obviously, and very unabashedly installing Communist regimes in Eastern Europe, and what cause had they to imagine the Russians not having similar designs on the whole of the Korean Peninsula, to say noth-

7 Lowe, Peter. The Origins of the Korean War (London: Longman, 1986), 23-25. Yoo, Theodore Jun. The Koreas: The Birth of Two Nations Divided (Berkley: U California Press, 2020), 17-18. 
ing of its upper half? ${ }^{8}$

As for his thoughts on the Korean War's culpable, aggressor side, Abrams takes, of course, the revisionist view and then some. Specifically, downplayed in his recounting of things is the fact of the North's sending some 75,000 to 90,000 of its troops over the ramparts of the 38th parallel in the early morning of June 25, 1950, while emphasized are these other facts: the leadership of the South having itched for a fight for years; both leaderships' having initiated border skirmishes of various sizes prior to the just-named June day; and, lastly, a civil war virtually indistinguishable from the War per se having been in progress up and down the peninsula since at the very least Japan's withdrawal. ${ }^{9}$ And then too, further and beyond that, he argues that a failed and failing Syngman Rhee-led South needed a war to save it from the humiliation of a popularly supported reunification that, when it happened, would almost certainly favor the North's developing political system. As for the Americans, they too had reasons to want a war on the Korean Peninsula, says Abrams. Or, at the very least, those of the hardline anti-Communist persuasion, such as General Douglas MacArthur - who was at that time no less a person than the Supreme Commander for the Allied Powers and overseer of the nearby Japan's reconstruction - had a reason to want such a war, namely, the pretext it would offer to confront and rebuke the "red menace" a-growing in China since the triumph of Mao's forces over Chiang Kai-shek's in October of 1949. And, lastly, Abrams points to a fuzzily dated ROKAF attack on the North Korean city of Haeju as the War's likely triggering event. Yes, what to say in response to these arguments against assigning the aggressor's role to the North in the War's regard, for that is of course

8 Lowe, Peter, 31-32.

Hastings, Max. The Korean War (New York: Simon \& Schuster, 1987), 44.

9 Stanley Sandler. The Korean War: No Victors, No Vanquished (Lexington: The University Press of Kentucky, 1999), 28-45, https://search.ebscohost.com/login.as px?direct=true $\& \mathrm{db}=\mathrm{e} 089 \mathrm{mna} \& \mathrm{AN}=938401 \&$ site $=$ ehost-live .

Harding, Blaine. King of Spies: The Dark Reign of America's Spymaster in Korea (New York: Viking, 2017), 39-40. 
the point toward which Abrams's researches lead? Only this: that those motives assigned to Syngman Rhee for wanting war-namely, discontent in his ranks and in his populace, not to mention ambition-are equally assignable to Kim Il-sung. Again, the numbers 75,000 and 90,000 are large and war-declarative so to speak, as well as too unmatched by any numbers of soldiers alleged to have been sent by the South into the North prior to the day South Koreans today recall as "625 Day" (육이오). And, lastly, if the Americans and Rhee so much wanted war, how to explain their embarrassing and catastrophic ill-preparedness for the incursion that did indeed happen - inclusive of the former's near complete withdrawal of its troops from the Peninsula in '48 and '49? Was that illpreparedness nothing more than an expensive act of provocation? Abrams's account of the War's beginnings would require us to think it so.

The six chapters of Abrams's text that cover the War's three activeshooting years say everything that one would expect, given the Leftist, anti-American take on things of his first chapters: that the early fighting's going entirely the North's way was a function of the rightness of its cause and the better morale of its troops; that American underestimates of the KPA's (North Korean military's) abilities in the early war were based in racism; that MacArthur's invasion via Inchon was tactically more like a no-brainer than a stroke of genius, and, beyond that, not nearly so determinative militarily as the huge advantages in firepower and logistics enjoyed by the American-led UN Command relative to those sustaining the KPA; that finding themselves in need of retreat, the KPA did so with admirable self-control, refraining, that is, from anything like the "scorched earth" behaviors that had characterized the ROKAF retreat just a few months earlier. And so on in these chapters, until eventually Abrams has made these other points too: that the continuation of the War beyond its equilibrious, late-fall $1950,38^{\text {th }}$-parallel moment was entirely the American-led UN Command's over-reaching fault; that they, the Americans, got what they deserved when the PVA (Chinese military) and KPA pushed back far more resolutely than they, the Americans, anticipated; that "absolute destruction" became the American air-war's intent, 
while, on the ground, "all Koreans are the enemy" was its de facto policy; that in the execution of these two strategies all manner of sinister weaponry were employed (biological, chemical, radioactive); and that, lastly, as a result of their no-holds-barred tactics, the Americans got far more than they deserved in the armistice that was eventually signed.

And what to say in response to these, Abrams's (as well as, you might have noticed, the DPRK's) Korean War talking points-beyond, that is, acknowledging the dispiriting grains of truth out of which most of them, like genetically modified bushes, are grown? Next to nothing, for transparent, believe me, is the genetic modification. I say this on the basis of my readings in more balanced accounts of the War. For, yes, even the least boosterish of the Korean War's American historians-I.F. Stone and Bruce Cummings among them-recognize in various of their pages the Armageddon-like trajectories that wars, regardless of their actors, mostly take, and recognize, too, that both sides do a lot of killing. If these recognitions inhabit Abrams's text, I missed them. I also say it on the basis of that note in one of his elsewhere published author's bios that credits Abrams with having "published widely on defense and politics under various pseudonyms [emphasis mine]. ${ }^{10}$ Yes, if that isn't the giveaway of something less than honest being afoot here, say I, an English professor by trade, I don't know what is. For though many a good novel has been written under a pen name, I am not aware of any first-rate histories having been produced by writers whose names are a ruse. And, lastly, I say it on the basis of the staggering number of Abrams's endnotes in, not just this section of his book, but in its whole. That great number suggests not a corporal, thinking, and feeling authorial reader but instead a robotic scanner/collator of one propagandistic AI/team-of-writers sort or another. Yes, who could have read the more than 140 books and articles that are listed, for example, as the sources of Abrams's tenth chapter? And what document did he actually have in hand when, in seeking to support his claim of

10 “A.B. Abrams." Daily NK. https://www.dailynk.com/english/author/ababrahms/. Accessed Dec. 8, 2021. 
the American use of biological weapons in the War (138-144), he quotes a sentence that his text says comes from somewhere in a 600-page report issued by a World Peace Council's International Scientific Commission (138) even as the text's associated endnote says he got it from the $1652^{\text {nd }}$ page of a document called "Hearings United States Congress House Committee on Un-American Activities" (149)?

Are you getting my drift here? Impossible, say I, is Abrams's presentation of himself as an unsalaried, individual researcher (and unconvincing are his photo-less, print interviews). ${ }^{11}$ Also impossible is the thesis of his first post-Armistice chapter, "Proxy Wars: How North Korea and America Wage War Through Third Parties"-wherein he argues that no small number of America's manifold involvements in regional wars in the last century's second half - think Vietnam in the 60s and 70's, think Egypt in the 1970s, think Syria in the 1980s and 2010s, think Libya in the 1980s and 1990s, and so on-were in actual fact engagements with North Korea. Again, impossible, mea culpa, was my reading beyond that lunatic chapter. And, lastly, impossible is my choice in the alternatives I mentioned at the start of this review. Yes, its limitations notwithstanding, I'll stay with Cha's The Impossible State rather than move on to Abrams's Immovable Object.

11 "Interview with Expert A.B. Abrams: The Future of North Korean Security and Conflict with the United State-Part I." Force Comparison, Jan. 15, 2021, https://militarywatchmagazine.com/article/interview-with-expert-a-b-abrams-thefuture-of-north-korean-security-and-conflict-with-the-united-states-part-two. Accessed December 8, 2021. 
